\title{
Treatment of Gingival Recessions in Heavy Smokers Using Two Surgical Techniques: A Controlled Clinical Trial
}

\author{
Danilo M. REINO \\ Arthur B. NOVAES Jr \\ Luciana P. MAIA \\ Daniela B. PALIOTO \\ Márcio F. M. GRISI \\ Mário TABA Jr \\ Sérgio L. S. SOUZA
}

\begin{abstract}
Department of Surgery, Oral and Maxillofacial Traumatology and Periodontology, Ribeirão Preto Dental School, USP - University of São Paulo, Ribeirão Preto, SP, Brazil
\end{abstract}

\begin{abstract}
Smokers have small root coverage which is associated with bad vascularity of periodontal tissues. This study evaluated a technique that can increase the blood supply to the periodontal tissues compared with a traditional technique. Twenty heavy smokers (10 males and 10 females) with two bilateral Miller class I gingival recessions received coronally positioned flaps in one side (Control group) and extended flap technique in the other side (Test group). Clinical measurements (probing pocket depth, clinical attachment level, bleeding on probing, gingival recession height, gingival recession width, amount of keratinized tissue, and width and height of the papillae adjacent to the recession) were determined at baseline, 3 and 6 months postoperatively. Salivary cotinina samples were taken as an indicator of the nicotine exposure level. No statistically significant differences $(\mathrm{p}>0.05)$ were detected for the clinical measurements or smoke exposure. Both techniques promoted low root coverage (Control group: $43.18 \%$ and Test group: $44.52 \%$ ). In conclusion, no difference was found in root coverage between the techniques. Root coverage is possible and uneventful even, if rather low, in heavy smoker patients with low plaque and bleeding indices.
\end{abstract}

Key Words: smoking, connective tissue, plastic surgery.

\section{INTRODUCTION}

Aesthetics has recently received great attention in our society, which led to an increased demand for periodontal plastic surgeries. Gingival recessions are the most common aesthetic gingival problems, easy to be perceived by the patients and reaching more than $50 \%$ of the population in Brazil and USA $(1,2)$. Thus, periodontal plastic surgeries for root coverage have become the most frequently sought by patients (3). Apart from esthetic reasons, periodontal plastic surgeries have also been indicated for the treatment of gingival recession due to dentin hypersensitivity, difficulty to remove dental plaque and occurrence of root dental caries (4).

A number of predisposing factors for gingival recession can be cited: trauma to the gingival tissues during toothbrushing, alveolar bone dehiscence, periodontal disease (5), abnormal tooth positioning, thin attached gingiva (6), labial frenum (7), and iatrogenic factors. Amid those predisposing factors, the habit of smoking has also received a great deal of attention, as smokers have higher prevalence, extension and severity of gingival recessions when compared with non-smokers (1). Clinical studies have revealed reduced root coverage in terms of quantity and stability, when comparing smoking and non-smoking patient groups (8-11).

The root covering technique described by Langer and Langer (12), provides the most predictable results among the existing techniques $(4,13)$. However, studies comparing smoking and non-smoking patients under root coverage procedures reported a negative influence of smoking on treatment predictability $(3,11,14,15)$.

The mechanism by which smoking affects periodontal plastic surgery outcomes remains unclear

Correspondence: Prof. Dr. Sérgio Luis Scombatti de Souza. Faculdade de Odontologia de Ribeirão Preto, USP, Departamento de CTBMF e Periodontia. Avenida do Café, s/n, Monte Alegre, 14040-904 Ribeirão Preto, SP, Brasil. Tel: +55-16-3602-3980. e-mail: scombati@forp.usp.br 
(10), but smoking interferes with several physiological mechanisms and cellular functions (16). The large number of tobacco toxins may impair periodontal healing (3). Smoking also decreases periodontal blood flow $(14,15,17)$, compromising graft vascularization (14) and subepithelial connective tissue graft (SCTG) outcomes.

In order to achieve higher vascularization levels in periodontal plastic surgery procedures with acellular dermal matrix, Barros et al. (18) described a new technique, which consisted in extending the flap with vertical incisions to the adjacent teeth to the recession area to be covered. The results were better than those obtained by Langer and Langer technique (12): there were an increased number of blood vessels nourishing the graft, improved healing process and better root coverage.

This new technique may increase root coverage in smokers, improving graft vascularity. Thus, in the light of all negative results shown by conventional root coverage techniques in smoking patients, and weighing the positive results of a new extended flap technique that could improve vascularization of the grafted tissue, the aim of this study was to compare these techniques combined with SCTG in smoking patients, through clinical, histological and lab analyses.

\section{MATERIAL AND METHODS}

\section{Patient Selection}

Twenty patients ( 10 females and 10 males), aged between 35 and 50 years and with at least 20 teeth, were selected. The patients were screened at the Ribeirão Preto Dental School, University of São Paulo, Brazil, between March and October 2008. A flow diagram of the study participants is presented in Figure 1.

All patients were current heavy smokers (20 or more cigarettes per day for more than 5 years) and had aesthetic complaints related to gingival recession. Inclusion criteria were: bilateral gingival recession, Miller (19) class I or II, with $3 \mathrm{~mm}$ in height and less than $3 \mathrm{~mm}$ of keratinized tissue in non-molar teeth. Exclusion criteria were: HIV-positive, diabetes, pregnancy, medical history of hepatitis and periodontal pocket combined with recession or adjacent teeth. All patients agreed with the study protocol and signed an informed consent form prior to treatment. For ethical reasons, patients were encouraged to stop smoking for the known health benefits, and tobacco cessation information was provided upon request. The study was approved by the institutional
Ethics Committee (Protocol \#2008.1.170.58.4).

\section{Clinical Procedures}

The patients received general oral hygiene instructions to eliminate habits related to the etiology of the gingival recessions. They were also subjected to scaling and root planing and prophylactic therapies, and were taken to the maintenance phase of the treatment with weekly-controlled evaluations. The surgical procedures were carried out when gingival bleeding and plaque indices were lower than $20 \%$. Full-mouth plaque score was recorded as the percentage of total surfaces (six sites per tooth) that had plaque (20). Bleeding on probing was assessed dichotomously and was recorded as the percentage of total surfaces (6 sites per tooth) that exhibited bleeding on probing (21).

Two teeth in the same arch, bilaterally (Fig. 2 A,B), were included in the study. Clinical measurements were taken before the surgical treatment (Baseline), 3 and 6 months after surgery at the mid-buccal point of the involved tooth: a) probing pocket depth (PPD), b) clinical attachment level (CAL), c) bleeding on probing (BOP), d) gingival recession height (RH) (Fig. $2 \mathrm{~A}, \mathrm{~B}), \mathrm{e}$ ) gingival recession width (RW), f) amount of keratinized tissue, g) width of the papillae adjacent to the recession, h) height of the papillae adjacent to the recession. Clinical examinations were always carried out by the same operator. Masking of the examiner was not practical because it was possible to observe where the incisions were made at the site. Thus, it was impossible to hide which treatment each site received. Computed force-controlled periodontal probe (Florida Probe Corporation, Gainesville, FL, USA) was used for PPD and CAL, and manual periodontal probe $(\mathrm{Hu}-$ Friedy, Chicago, IL, USA) was used to measure the other clinical parameters.

At the same examinations (initial, 3 and 6 months post-surgery) saliva was collected from the patients for evaluation of cotinine levels at a later moment. All sample collection was carried out in the morning (approximately at $9 \mathrm{o}$ 'clock - with a maximum tolerance of $15 \mathrm{~min}$ after or before the designated period) to avoid possible alterations in salivary composition. In order to avoid sample contamination, the patients were instructed not to eat, consume alcohol, perform oral hygiene and rinse the mouth with water $60 \mathrm{~min}, 24 \mathrm{~h}, 30 \mathrm{~min}$ and $10 \mathrm{~min}$, respectively, prior to saliva collection. Patients coughed up saliva for $5 \mathrm{~min}$ and deposited saliva into 
sterile plastic tubes by inclining their heads to avoid the inclusion of air bubbles. After saliva collection, the contents of the tubes were transferred to type 3810 microtubes (Eppendorf do Brasil Ltda., São Paulo, SP, Brazil) and stored at $-80^{\circ} \mathrm{C}$ until the analysis.

\section{Surgical Procedures}

All surgical procedures were performed by the same periodontist. Two surgical procedures were performed in each patient: in one side, Langer and Langer technique (12) was used (Control group - CG), and in the contralateral side the technique described by Barros et al. (18) was performed (Test group - TG). Both procedures utilized SCTG. The side and the corresponding technique to be used were randomly chosen by coin toss.

The technique used in CG consisted of an intracrevicular incision in the buccal face of the selected tooth followed by mesial and distal releasing incisions in the same tooth, without including the adjacent papillae (Fig. 3A). A partial thickness flap was raised beyond the mucogingival junction, and its base was released to cover coronally and passively the gingival recession and the graft. In TG, the technique consisted an intracrevicular incision was performed on the buccal face of the recession-compromised tooth, which included both adjacent teeth as well (Fig. 3B). A releasing incision was performed mesially and another one distally of the adjacent teeth closest to the element to be treated, without including the adjacent papillae. A partial thickness flap was raised beyond the mucogingival junction and after its base was released, the flap was displaced coronally to passively cover both the gingival recession and graft.

Following flap deflection, both groups received root planing and scaling in the exposed areas using Gracey curettes \#5 and \#6, and the area was rinsed abundantly with sterile saline.

The graft was removed from the patient's palate (22) and trimmed using Goldman-Fox scissors for improved adaptation on the gingival recession areas. After graft removal, the following trans-surgical parameters were measured: a) flap thickness; b) graft

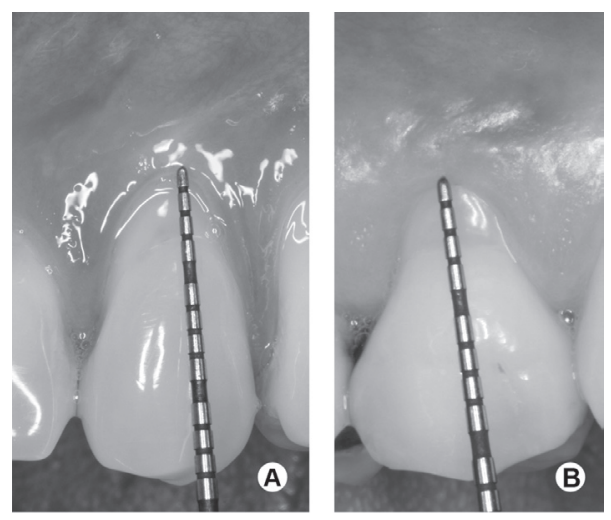

Figure 2. Preoperative view of the Control(A) and Test(B) groups.

Figure 1. Flowchart for the study patients. $\mathrm{TG}=$ Test group; $\mathrm{CG}$ $=$ Control group.
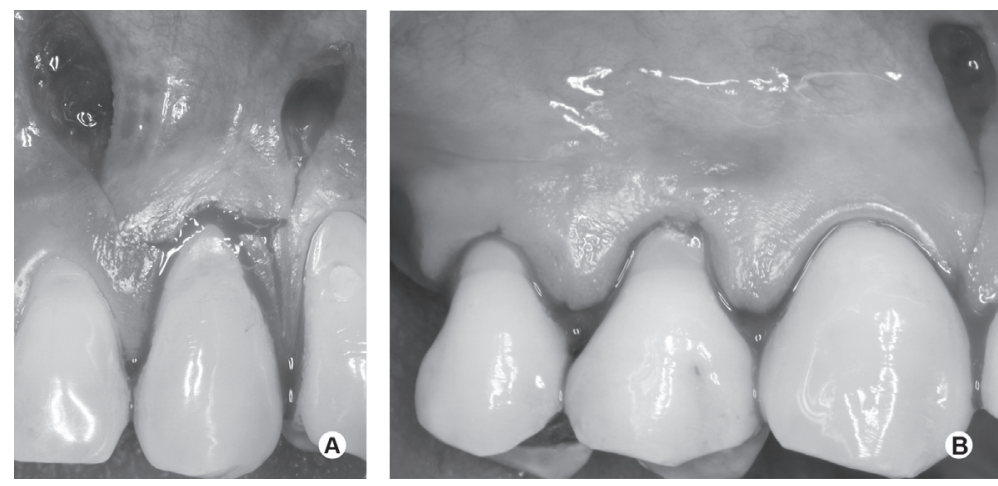

Figure 3. Incisions performed in Control group (A) and in the Test group (B). 
thickness; c) graft length; d) graft width. Parameters "a" and " $b$ " were measured using a digital surgical caliper with sterilizable and removable tips (Mitutoyo Sul Americana, Suzano, SP, Brazil), and the remaining parameters were measured using a notched manual North Carolina periodontal probe.

At this stage, tissues from the donor and receptor sites were collected for histological and histomorphometrical analyses. The palate graft was removed with a $2-\mathrm{mm}$ safety margin. The area in excess was trimmed out and prepared for histological and histomorphometrical analyses, as described later. Furthermore, a fragment (at least $3 \times 3 \mathrm{~mm}$ ) was removed from the internal side of the receptor site flap using a new $15 \mathrm{C}$ blade, and was also prepared for histological and histomorphometrical analyses.

The graft was sutured to the receptor site using sling sutures with absorbable 5.0 (Vicryl; Ethicon, Somerville, NJ, USA) sutures (Fig. 4A,B). The flap was displaced coronally to completely cover the area, and was sutured to this position as previously described (Fig. 5
A,B). The donor site received 4.0 silk sutures (Ethicon). All patients were instructed to discontinue tooth brushing and reduce or stop smoking. A $0.12 \%$ chlorhexidine digluconate solution was prescribed as a mouth rinse to be used twice a day for 15 days; thereafter, the patients were instructed to clean the operated area with cotton swabs embedded in the same solution. Analgesics were prescribed for 3 days. Sutures in the donor site were removed after 7 days, and in the areas where root coverage was required, after 15 days. Thirty days later, the patients were allowed to carefully resume toothbrushing over the operated area. The patients returned for reinstruction on oral hygiene procedures and prophylactic control at 2 and 4 weeks post-surgery, and then monthly until 6 months post-surgery had passed.

\section{Histological and Histomorphometrical Analyses}

The tissues removed from the palate and internal side of the flap (as previously described) were immediately fixed in a $10 \%$ formalin solution for $24 \mathrm{~h}$ and then embedded in paraffin. Semi-serial longitudinal 7 - $\mu \mathrm{m}$-thick sections were obtained. Two sections from each region (palate and marginal gingiva) were stained using hematoxylin and eosin (HE) and another two were stained with Masson's Trichrome for each one of the studied groups.

The methodology described by Souza et al. (15) was followed for the histomorphometrical analysis. The histological and histomorphometrical analyses were carried out by a single operator blinded to the study groups. The samples stained with $\mathrm{HE}$ and Masson's Trichrome were examined under light microscopy for evaluation and description of the histological structures present in each region (palate and marginal gingiva) and in each group (CG and TG). For detection and quantification of blood vessels, samples that had been prepared for immunohistochemical analysis were reviewed and photographed under a light microscope connected to a video camera (Olympus BX50; Olympus Corporation, Tokyo, Japan). An image analysis software (Image ProPlus 4.5;

Figure 5. The flap was positioned coronally to completely cover the graft and was sutured in position. Control (A) and Test (B) groups. 
Media Cybernetics, Inc., Bethesda, MD, USA) was used for histomorphometrical analysis of the captured images. Two sections from each biopsy were analyzed. The blood vessels from two consecutive fields in the central portion of the samples were counted and the obtained average number was considered as the blood vessel density of the sample. The average from both samples was considered the blood vessel density of the evaluated site (palate or marginal gingiva of $\mathrm{CG}$ and TG), and was expressed as number of vessels per field at $\times 200$ resolution $(\times 20$ on the objective lenses and $\times 10$ on the ocular lens). Any brown-stained endothelial cell, clearly detached from the adjacent blood vessels and from other elements, such as connective tissue, was regarded as a single vessel. It was not necessary vessel lumen to be present for the structure to be considered a vessel. Neither was necessary the presence of red or other blood cells to define a vessel lumen (23).

\section{Saliva Cotinine Analysis}

Cotinine is a metabolite from nicotine that allows monitoring patient exposure to nicotine (14). Cotinine levels were detected through enzyme-linked immunosorbent assays (ELISA) (Salimetrics Inc., State College, PA, USA) using a kit for quantitative analysis of cotinine in saliva following manufacturer's instructions.

\section{Statistical Analysis}

The study was powered to detect a minimum clinically significant difference in root coverage of $1 \mathrm{~mm}$, using a significance level of 5\%. For a power level of $80 \%, 17$ patients would be necessary. Statistical analysis was comparative and parametric $(n=20)$. Descriptive statistics are expressed as mean and standard deviation. The percentage of root coverage and decrease in width gingival recession were calculated after 3 and 6 months using the formula: (baseline parameter -3 or 6 month parameter) /baseline parameter x 100 .

One-way ANOVA was used to evaluate differences between CG and TG at baseline and in the 3-month and 6-month postoperative periods for $\mathrm{RD}$, CAL, KTH, PPD, RW, keratinized mucosa height, keratinized mucosa thickness, base of the mesial papilla, base of the distal papilla, mesial papilla height, distal papilla height, root coverage, decrease in width gingival recession and cotinine level.

Two-way ANOVA was used to compare the clinical parameters related to the surgical techniques and to the time intervals (intra-group difference: Baseline $\mathrm{x}$ 3 months, Baseline x 6 months). In case of significance, the Bonferroni t test was applied as a multiple comparison test. For all statistical analyses, $\mathrm{p}<0.05$ was considered.

$\mathrm{T}$ test was used to compare CG and TG transsurgical clinical parameters (flap thickness, graft length, graft width and graft thickness).

\section{RESULTS}

\section{Clinical Data}

Both surgical techniques were performed in all patients, and a total of 40 gingival recessions were treated: $20 \%$ of the recessions treated were on maxillary first premolars, $50 \%$ in mandibular first premolars, $20 \%$ in maxillary canines and $10 \%$ in mandibular canines. Both groups presented similar pretreatment clinical values, with no statistically significant difference $(p>0.05)$ for PPD, CAL, RH or RW, keratinized mucosa height and keratinized mucosa thickness (Fig. 6). There was no statistically significant difference $(p>0.05)$ for either the base of the mesial or distal papilla or the height of the mesial or distal papillae in terms of recession (Fig. 6).

Regarding the trans-surgical clinical parameters obtained during the surgical procedures, there was no statistically significant difference $(p>0.05)$ for flap thickness, connective tissue width and thickness (data not show), but statistically significant difference was founded for SCTG length (CG: $11.97 \pm 1.93 \mathrm{~mm}$; TG: $14.97 \pm 3.69 \mathrm{~mm} ; \mathrm{p}=0.01$ ). This can be explained because the releasing incisions next to the gingival recession in CG technique restricted graft length.

All patients recovered with no sort of complications and during the entire follow up period all patients presented bleeding and plaque indices inferior to $20 \%$. The results obtained after 3 and 6 months in the comparison between groups did not demonstrate any statistically significant differences for the clinical parameters analyzed (Fig. 6).

Intra-group analysis revealed statistically significant reduction in recession sizes after 3 months and 6 months (Fig. 7 A,B) when compared with the pretreatment period $(p<0.01)$, for both surgical techniques. However, there was no statistically significant difference between the results obtained at 3 and 6 months. Comparison between CG and TG at 3 and 6 months did no show statistically significant difference. The same 
analysis showed no statistically significant differences for RW reduction in the inter-group and intra-group comparisons. Even though the surgical procedures increased the height and thickness of the keratinized mucosa, the intra-group and inter-group analyses did not show any statistically significant difference $(p>0.05)$.

Although root coverage and reduction of RW and RH in TG were numerically superior to $C G$, no statistically significant difference ( $p>0.05$ ) was found.

\section{Laboratorial Data}

Cotinine analysis demonstrated that the patients were similarly exposed to tobacco-composing chemicals during the evaluation period (pretreatment: $416 \pm 283$ $\mathrm{ng} / \mathrm{mL} ; 3$ months: $393 \pm 260 \mathrm{ng} / \mathrm{mL}$ and 6 months: 310 $\pm 145 \mathrm{ng} / \mathrm{mL} ; \mathrm{p}=0.34$ ).

Histological analysis revealed absence of inflammatory infiltrate and presence of dense connective tissue, blood vessels, endothelial cells, collagen fibers and fatty tissue cells in the palate (Fig. 8) and flap biopsies (Fig. 9). Histomorphometrical analysis did not demonstrate statistical significance for blood vessel quantification when inter-group comparisons were performed. However, the flap exhibited less blood vessels than the palate graft $(p<0.05)$ (Fig. 10).
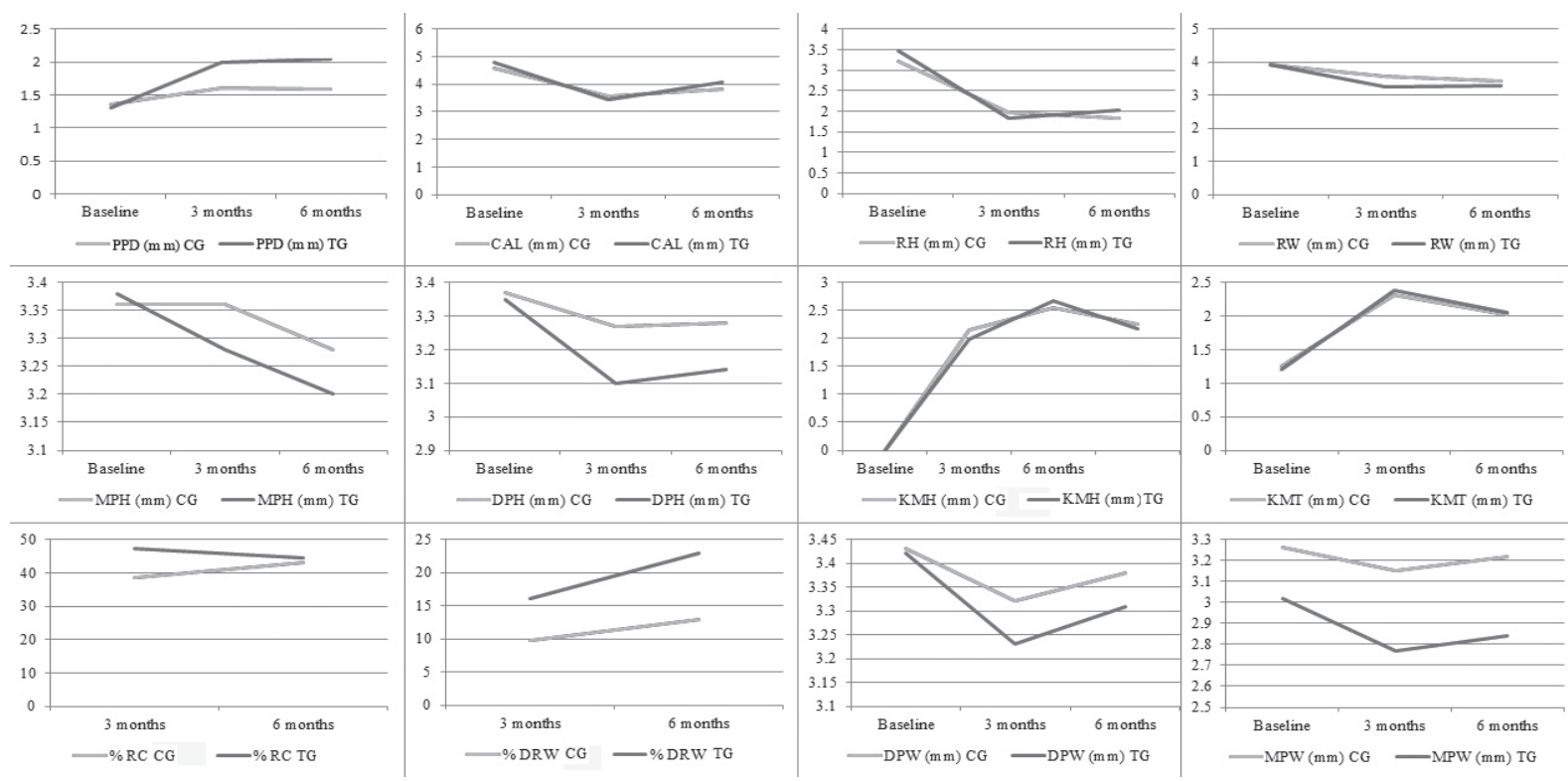

Figure 6. Clinical parameters and cotinine levels at baseline, 3 and 6 months postoperatively for the Test and Control Groups. N=20 patients. $\mathrm{PPD}=$ probing pocket depth, $\mathrm{CAL}=$ clinical attachment level, $\mathrm{RH}=$ recession height, $\mathrm{RW}=$ recession width, $\mathrm{KMH}=$ keratinized mucosa height, KMT = keratinized mucosa thickness, DPW = base of the distal papilla, MPW = base of the mesial papilla, $\mathrm{MPH}=$ mesial papilla height, $\mathrm{DPH}=$ distal papilla height, $\% \mathrm{RC}=$ root coverage, $\% \mathrm{DRW}=$ decrease in width of gingival recession .
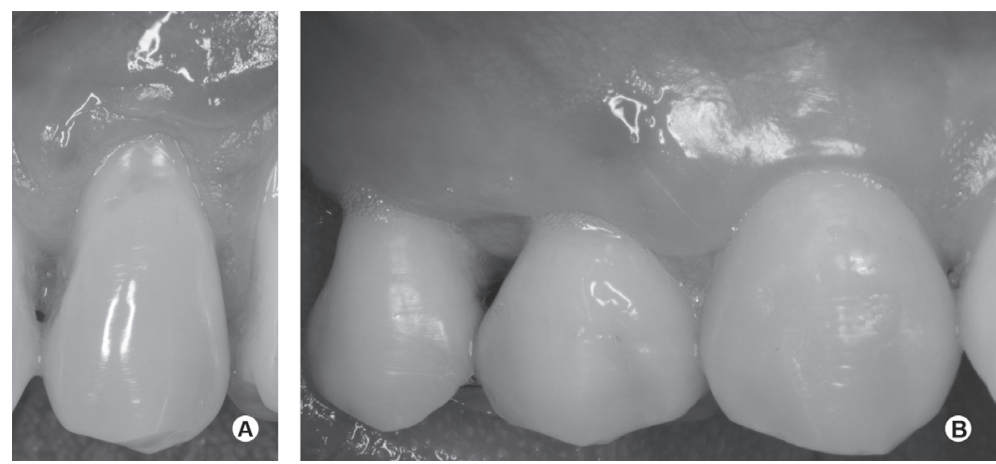

Figure 7. Clinical outcome after 6 months. $\mathrm{A}=$ Control group; $\mathrm{B}=$ Test group. 


\section{DISCUSSION}

The aim of this study was to use a new technique for root coverage (TG - Barros' et al. technique) (18), comparing it with the commonly used technique (CG Langer and Langer's technique) (12) for the treatment of gingival recessions in heavy smokers. The proposed treatments were capable of reducing recession height.

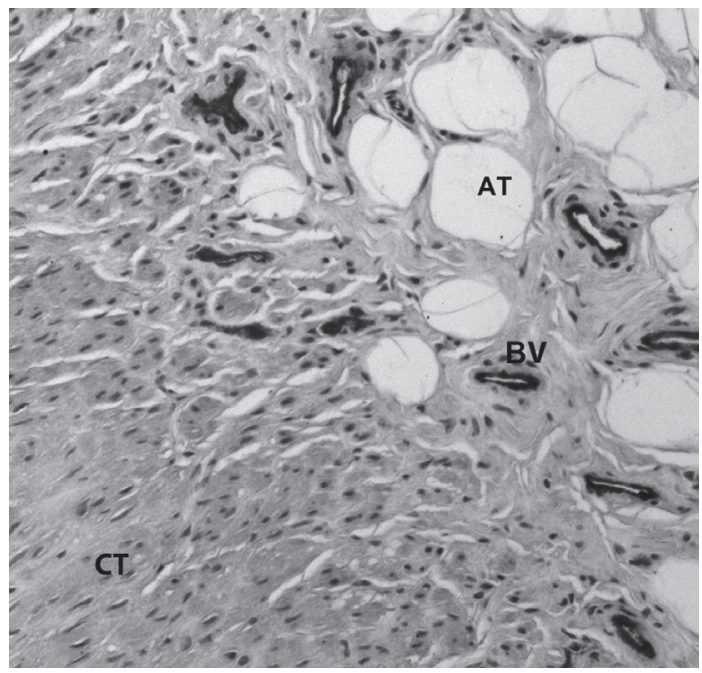

Figure 8. Histological biopsies from SCTG. Representative examples of blood vessel density: Endothelial cells are marked in brown, original magnification $\times 20$. $\mathrm{AT}=$ adipose tissue, $\mathrm{BV}=$ blood vessel, $\mathrm{CT}=$ connective tissue.

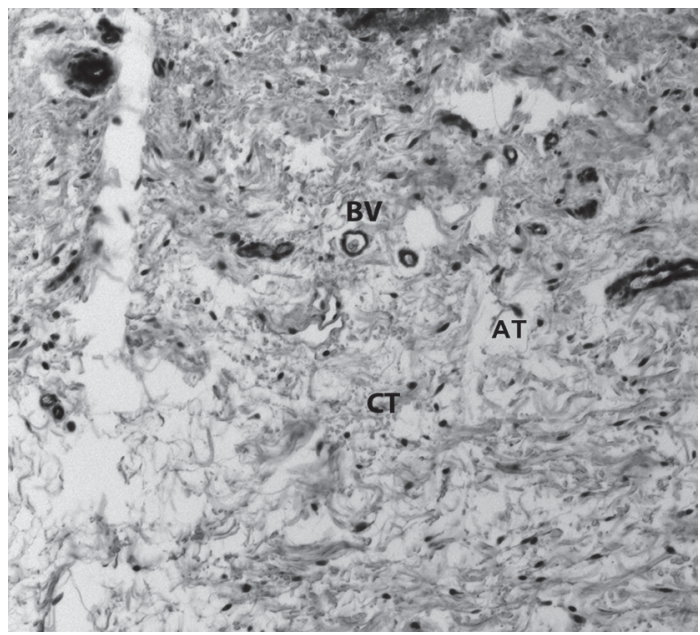

Figure 9. Histological biopsies from receptor site. Representative examples of blood vessel density: Representative examples of blood vessel density: Endothelial cells are marked in brown, original magnification $\times 20$. $\mathrm{AT}=$ adipose tissue, $\mathrm{BV}=$ blood vessel, $\mathrm{CT}=$ connective tissue
There was intra-group statistically significant difference $(\mathrm{p}<0.01)$, but root coverage obtained with in $\mathrm{CG}$ after $3(38.39 \%)$ and 6 months (43.18\%) and in TG after 3 (47.25\%) and 6 months (44.52\%) was low and did not show any significant difference between groups. The same occurred with recession width reduction in CG after $3(9.79 \%)$ and 6 months $(12.88 \%)$ and in TG after $3(15.99 \%)$ and 6 months $(22.91 \%)$. The literature has shown that smokers exhibit worse results in gingival recession treatment than non-smokers with or without the use of SCTG $(3,9,10,14,15)$.

The low values for root coverage obtained in the present study for both techniques agree with the findings of another study (3), which treated heavy smokers (more than 20 cigarettes per day) and non-smokers with the use of SCTG and attained average root coverage of $58.84 \%$. Another study (11) also used SCTG in heavy smokers and obtained only $50 \%$ of root coverage after 2 years of follow up. Similar results were also presented by Souza et al. (15), who treated patients who smoked more than 10 cigarettes per day and obtained $58.02 \%$ of root coverage after 6 months.

Great part of the studies differ when it comes to the quantity of tobacco consumed by the patient, generating difficulties in terms of result comparison. As part of the solution for this problem, Erley et al. (14) used cotinine analysis in the saliva, as a biomarker for nicotine exposure, and the results showed a high correlation $(\mathrm{r}=0.97)$ between cotinine and reduced root coverage. Therefore, this condition would be of dosedependent sort: the more exposed to tobacco the patients were, the less root coverage they would obtain. After 6 months, Erley et al. (14) showed average root coverage in heavy smokers rated at $76.6 \%$. One of the possible explanations for this higher value, when compared with

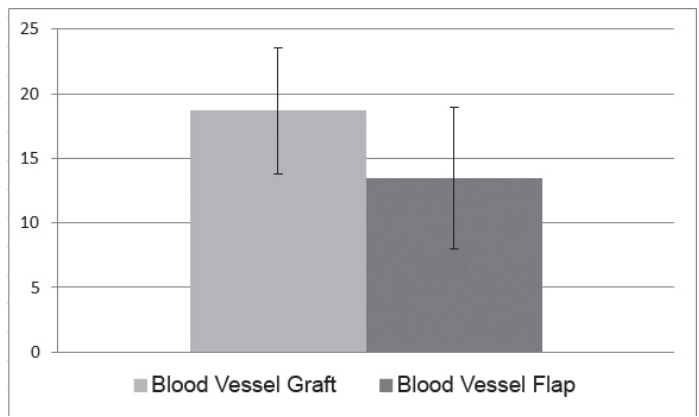

Figure 10. Blood vessel count averages (vessels per $\times 200$ field) in biopsies from grafts and flaps. Differences between grafts and flaps were statistically significant (Mann Whitney test, $\mathrm{p}<0.0001$ ). 
the present study (CG: $43,18 \%$ and TG: $44,52 \%$ ), is a possible reduced tobacco consumption in the Erley's selected sample after the surgical procedures, since there was no monitoring of tobacco exposure throughout the follow up stages, as cotinine analysis was only carried out at the pretreatment period.

The present study is the first one to verify cotinine levels in three distinct periods as a monitoring method for patient exposure to tobacco during the healing process after periodontal plastic surgery procedures. The guidelines of the salivary assay used in this study are: no smoker (cotinine level $=<15 \mathrm{ng} / \mathrm{mL}$ ), secondhand smoker (cotinine level $=10-50 \mathrm{ng} / \mathrm{mL}$ ), light smoker (cotinine $=51-100 \mathrm{ng} / \mathrm{mL})$, moderate smoker (cotinine $=101-200 \mathrm{ng} / \mathrm{mL}$ ) and heavy smoker (cotinine $=>$ $201 \mathrm{ng} / \mathrm{mL}$ ). The mean cotinine values did not differ significantly between Baseline $(416 \pm 283 \mathrm{ng} / \mathrm{mL}), 3$ months $(393 \pm 260 \mathrm{ng} / \mathrm{mL})$ and 6 months $(310 \pm 145$ $\mathrm{ng} / \mathrm{mL}$ ), but were much higher than those reported by Erley et al. (14), probably due to the higher cigarette consumption (20 units per day). Thereby, the exposure of these patients to smoking was steady throughout the studied period and tobacco interference occurred approximately in the same intensity and frequency during the entire study. These high levels of cotinine might have been the main cause for the low root coverage obtained in both studies. Smoking is also capable of limiting complete root coverage. After 6 months, this had occurred in only 2 cases ( $5 \%$ of the treated cases - data not show), both in TG, without statistically significant difference from CG. Souza et al. (15) reported full root coverage in $6.7 \%$ of the cases, while Erley et al. (14) obtained 25\% and Andia et al. (11) obtained none. These data are alarming for the daily practice because smokers might not be entirely satisfied with the aesthetic improvement through a small reduction in gingival recession and such a low predictability for full root coverage procedure. The damage caused by smoking seems to have been intense enough to make the majority of smoking patients of the present study yield a root coverage of less than $50 \%$ ( $67.5 \%$ of the cases), while for Souza et al. (15) the majority of smokers presented root coverage between $50 \%$ and $99 \%$ (60\% of the cases).

When it comes to the other clinical measurements, namely PPD, CAL, RH, RW, height and thickness of keratinized mucosa and height and base of mesial and distal papillae, there was no statistically significant difference between or within the groups. When it comes to the trans-surgical parameters, such as flap thickness, graft width and thickness, they did not differ significantly between the groups either. Only graft length was greater in TG $(14.97 \pm 3.69)$ than in CG $(11.97 \pm 1.93)$, which is justifiable as the conventional technique restricts graft length because it uses releasing incisions next to the gingival recession. These results demonstrate that there were no statistically significant differences for these variables between the surgical techniques.

In previous studies $(18,24)$, the TG technique increased the predictability of root coverage by, among other factors, allowing better vascularization of the flap and thus favoring a better healing process. However, in the present study, it did not demonstrate better efficacy than the CG technique. This may be attributed to the extreme damage to the periodontal and adjacent tissues from year after year of intense exposure to the several toxic substances from smoking. Souza et al. (15) counted blood vessels present in biopsies from subepithelial connective tissue and reported that smoking patients presented a mean value of $36.53 \pm 10.23$ vessels per checked field, corresponding to $30 \%$ less than nonsmoking patients. In this study, graft biopsies presented practically half the number of vessels reported by Souza et al. (15) (18.69 \pm 4.87$)$. This way, heavy smokers may have their vascular blood flow severely hampered, thus, jeopardizing blood supply to the graft and complicating periodontal healing and root coverage. The amount of vessels in the receptor site $(13.49 \pm 5.48)$ were even further reduced than that present in the grafts $(\mathrm{p}=0.0001)$, which suggests that smoking reduces tremendously vascularization in the receptor site, diminishing blood flow in these tissues, which may affect flap healing. This could be a seriously hindering factor for root coverage, since the grafts are nourished by blood vessels originated by the flap. Furthermore, Clarke (25) have demonstrated that smoking may lead to vasoconstriction and, so, reduction in gingival blood flow. Hence, the combination of small blood vessel numbers in grafts and flaps, vasoconstriction and reduced gingival blood flow may be highly endangering for root coverage techniques, being responsible for the difficulty in obtaining total root coverage and for the low predictability and stability of the results in this type of therapy.

This is the first study to verify exposure to smoking in more than one evaluation period, and also the first one to quantify the number of blood vessels present in the receptor site for SCTG. No difference was found in root coverage between the techniques. Root coverage is possible and uneventful even, if rather low, in heavy 
smoker patients with low plaque and bleeding indices.

\section{RESUMO}

Fumantes apresentam resultados ruins no recobrimento radicular, o que pode estar relacionado à má vascularização dos tecidos periodontais. O objetivo deste estudo foi avaliar uma técnica que pode aumentar a nutrição do tecido periodontal, comparando com uma técnica tradicional.Vinte fumantes pesados $(10$ homens e 10 mulheres) apresentando duas retrações bilaterais classe I de Miller receberam recobrimento radicular pela técnica de retalho posicionado coronalmente de um lado e pela técnica do retalho estendido no outro lado. Medidas clínicas (profundidade de sondagem, nível clínico de inserção, sangramento a sondagem, altura e largura da retração gengival, quantidade de tecido queratinizado, altura e largura das papilas dos dentes adjacentes a retração gengival)foram realizadas no início do estudo, 3 e 6 meses de pós-operatório. Amostras salivares foram feitas para detectar cotinina, um indicador do nível de exposição ao fumo. Não foram detectadas diferenças estatisticamente significantes ( $>00,05)$ para os parâmetros clínicos ou exposição ao fumo. Ambas as técnicas tiveram baixo recobrimento radicular (controle: $43,18 \%$ e teste: $44,52 \%$ ). Nenhuma diferença estatisticamente significante foi encontrada para o recobrimento radicular entre as técnicas. Em pacientes fumantes pesados com baixo índice de placa e de sangramento gengival o recobrimento radicular é possível e comum, no entanto, o recobrimento é parcial.

\section{ACKNOWLEDGEMENTS}

The authors thank the State of São Paulo Research Foundation, São Paulo, SP, Brazil (FAPESP, grant 2007/08591-7 to Dr. Souza). Dr. Reino was supported by a scholarship from the Coordination for the Improvement of Graduated Personnel, Brasília, DF, Brazil (CAPES). The authors report no financial relationships related to any products involved in this study.

\section{REFERENCES}

1. Susin C, Haas AN, Oppermann RV, Haugejorden O, Albandar JM. Gingival recession: epidemiology and risk indicators in a representative urban Brazilian population. J Periodontol 2004; $75: 1377-1386$.

2. Albandar JM, Kingman A. Gingival recession, gingival bleeding, and dental calculus in adults 30 years of age and older in the United States, 1988-1994. J Periodontol 1999;70:30-43.

3. Martins AG, Andia DC, Sallum AW, Sallum EA, Casati MZ, Nociti Junior FH. Smoking may affect root coverage outcome: a prospective clinical study in humans. J Periodontol 2004;75:586591.

4. Oates TW, Robinson M, Gunsolley JC. Surgical therapies for the treatment of gingival recession. A systematic review. Ann Periodontol 2003;8:303-320.

5. Loe H, Anerud A, Boysen H. The natural history of periodontal disease in man: prevalence, severity, and extent of gingival recession. J Periodontol 1992;63:489-495.

6. Ericsson I, Lindhe J. Recession in sites with inadequate width of the keratinized gingiva. An experimental study in the dog. J Clin Periodontol 1984;11:95-103.

7. Modeer T, Odenrick L. Post-treatment periodontal status of labially erupted maxillary canines. Acta Odontol Scand 1980;38:253-256

8. Chambrone L, Chambrone D, Pustiglioni FE, Chambrone LA, Lima LA. The influence of tobacco smoking on the outcomes achieved by root-coverage procedures: a systematic review. J Am Dent Assoc 2009;140:294-306.

9. Silva CO, Sallum AW, de Lima AF, Tatakis DN. Coronally positioned flap for root coverage: poorer outcomes in smokers. $\mathrm{J}$ Periodontol 2006;77:81-87.

10. Silva CO, de Lima AF, Sallum AW, Tatakis DN. Coronally positioned flap for root coverage in smokers and non-smokers: stability of outcomes between 6 months and 2 years. J Periodontol 2007;78:1702-1707.

11. Andia DC, Martins AG, Casati MZ, Sallum EA, Nociti FH. Root coverage outcome may be affected by heavy smoking: a 2 -year follow-up study. J Periodontol 2008;79:647-653.

12. Langer B, Langer L. Subepithelial connective tissue graft technique for root coverage. J Periodontol 1985;56:715-720.

13. Chambrone L, Sukekava F, Araujo MG, Pustiglioni FE, Chambrone LA, Lima LA. Root coverage procedures for the treatment of localised recession-type defects. Cochrane Database Syst Rev 2009:CD007161

14. Erley KJ, Swiec GD, Herold R, Bisch FC, Peacock ME. Gingival recession treatment with connective tissue grafts in smokers and non-smokers. J Periodontol 2006;77:1148-1155.

15. Souza SL, Macedo GO, Tunes RS, Silveira e Souza AM, Novaes AB, Jr., Grisi MF, et al.. Subepithelial connective tissue graft for root coverage in smokers and non-smokers: a clinical and histologic controlled study in humans. J Periodontol 2008;79:1014-1021.

16. Palmer RM, Wilson RF, Hasan AS, Scott DA. Mechanisms of action of environmental factors - tobacco smoking. J Clin Periodontol 2005;32 Suppl 6:180-195.

17. Morozumi T, Kubota T, Sato T, Okuda K, Yoshie H. Smoking cessation increases gingival blood flow and gingival crevicular fluid. J Clin Periodontol 2004;31:267-272.

18. Barros RR, Novaes AB, Grisi MF, Souza SL, Taba MJ, Palioto DB. A 6-month comparative clinical study of a conventional and a new surgical approach for root coverage with acellular dermal matrix J Periodontol 2004;75:1350-1356

19. Miller PD, Jr. A classification of marginal tissue recession. Int $\mathbf{J}$ Periodontics Restorative Dent 1985;5:8-13.

20. Silness J, Loe H. Periodontal disease in pregnancy. 3. Response to local treatment. Acta Odontol Scand 1966;24:747-759.

21. Ainamo J, Nordblad A, Kallio P. Use of the CPITN in populations under 20 years of age. Int Dent J 1984;34:285-291.

22. Lorenzana ER, Allen EP. The single-incision palatal harvest technique: a strategy for esthetics and patient comfort. Int J Periodontics Restorative Dent 2000;20:297-305.

23. Weidner N, Semple JP, Welch WR, Folkman J. Tumor angiogenesis and metastasis-correlation in invasive breast carcinoma. N Engl J Med 1991;324:1-8

24. Barros RR, Novaes AB, Jr., Grisi MF, Souza SL, Taba M, Jr., Palioto DB. New surgical approach for root coverage of localized gingival recession with acellular dermal matrix: a 12-month comparative clinical study. J Esthet Restor Dent 2005;17:156-164; discussion 164.

25. Clarke NG SB, Hirsch RS. The effects of intra-arterial epinephrine and nicotine on gingival circulation. Oral Surg Oral Med Oral Pathol 1981;52:577-582. 